\title{
Preemptive Analgesia in Single-Incision Laparoscopic Surgery
}

\author{
Eui Gon Youk \\ Department of Surgery, Daehang Hospital, Seoul, Korea
}

\section{See Article on Page 238-242}

The administration of local anesthetics into the wound before the incision (preemptive analgesia) has been demonstrated to reduce postoperative pain in many kinds of elective surgery such as inguinal herniorrhaphies [1], gynecological procedures [2], and appendectomies [3]. The concept of preemptive analgesia is based on the hypothesis that the most effective way to eliminate or reduce postoperative pain is to prevent nociceptive input from afferent stimuli to the central nervous system so that central nervous system hyperexcitability does not occur [4]. Local tissue infiltration has many advantages: simplicity, safety, and low cost; the efficacy of this procedure has been investigated in several studies, but without reaching a clear conclusion that shows the real benefits of this technique [5].

An appendectomy is one of the most common emergency surgical procedures. However, few randomized clinical studies have been done to determine the efficacy of preemptive analgesia for postoperative pain relief after an appendectomy, and the results remain controversial [6,7]. Cervini et al. [7] demonstrated the benefit of preemptive bupivacaine infiltration by showing that it resulted in a decreased need for postoperative parenteral narcotics in patients undergoing a laparoscopic appendectomy. Kim et al. [8] reported that the total dose of analgesics in the 24 hours following surgery was not statistically significant, but the pain scores in the 24 hours after surgery were higher in patients who underwent a single-incision laparoscopic surgery (SILS)-appendectomy.

As the number of ports is reduced to one, the length of the single fascial incision tends to be longer. The length of the fascial in-

Correspondence to: Eui Gon Youk, M.D.

Department of Surgery, Daehang Hospital, 2151 Nambusunhwan-ro, Seocho-gu, Seoul 137-820, Korea

Tel: +82-2-6388-8114, Fax: +82-2-6388-8673

Email:youkgon@hanmail.net

(c) 2013 The Korean Society of Coloproctology

This is an open-access article distributed under the terms of the Creative Commons Attribution NonCommercial License (http://creativecommons.org/licenses/by-nc/3.0) which permits unrestricted noncommercial use, distribution, and reproduction in any medium, provided the original work is properly cited. cision is closely associated with postoperative wound pain [9]. The single umbilical incisions reported in other studies typically reached lengths of 15 to $20 \mathrm{~mm}$.

Although postoperative pain has not been a major concern since the introduction of the routine laparoscopic cholecystectomy (LC), supporters of a single-incision LC (SILC) advocate the hypothesis that a reduction in the number of incisions may result in lower postoperative pain. On the other hand, some authors believe that the SILC increases postoperative pain because of the additional stress on the port incision necessary to allow triangulation of the instruments and exposure or the longer incision at the port site. Previous meta-analyses showed no difference in pain on the day after surgery between the two approaches. In the present meta-analysis, no differences in postoperative pain were found up to 30 days after surgery [10].

The study of Ahn et al. [11] aimed to determine the efficacy of preincisional bupivacaine infiltration as preemptive analgesia in postoperative pain relief after an appendectomy especially in single-incision laparoscopic surgery. Bupivacaine, $0.5 \%$, was used as the local anesthetic for preincisional infiltration because it has a longer half-life than lidocaine and it has potential advantages for the relief of postoperative pain [12]. The study showed that preincisional bupivacaine infiltration was an effective and simple method of reducing postoperative pain for patients undergoing a SILS-appendectomy. Administration of preincisional bupivacaine infiltration may be worth considering for all patients undergoing an appendectomy, and it may be extended to other elective surgery as well.

\section{REFERENCES}

1. Tverskoy M, Cozacov C, Ayache M, Bradley EL Jr, Kissin I. Postoperative pain after inguinal herniorrhaphy with different types of anesthesia. Anesth Analg 1990;70:29-35.

2. Hannibal K, Galatius H, Hansen A, Obel E, Ejlersen E. Preoperative wound infiltration with bupivacaine reduces early and late opioid requirement after hysterectomy. Anesth Analg 1996;83: 376-81.

3. Lohsiriwat V, Lert-akyamanee N, Rushatamukayanunt W. Effica- 
cy of pre-incisional bupivacaine infiltration on postoperative pain relief after appendectomy: prospective double-blind randomized trial. World J Surg 2004;28:947-50.

4. Woolf CJ. Generation of acute pain: central mechanisms. Br Med Bull 1991;47:523-33.

5. Ko CY, Thompson JE Jr, Alcantara A, Hiyama D. Preemptive analgesia in patients undergoing appendectomy. Arch Surg 1997; 132:874-7.

6. Lewis DL, Thompson WA. Reduction of post-operative pain. $\mathrm{Br}$ Med J 1953;1:973-4.

7. Cervini P, Smith LC, Urbach DR. The effect of intraoperative bupivacaine administration on parenteral narcotic use after laparoscopic appendectomy. Surg Endosc 2002;16:1579-82.

8. Kim HO, Yoo CH, Lee SR, Son BH, Park YL, Shin JH, et al. Pain after laparoscopic appendectomy: a comparison of transumbilical single-port and conventional laparoscopic surgery. J Korean Surg Soc 2012;82:172-8.

9. Wei B, Qi CL, Chen TF, Zheng ZH, Huang JL, Hu BG, et al. Laparoscopic versus open appendectomy for acute appendicitis: a metaanalysis. Surg Endosc 2011;25:1199-208.

10. Trastulli S, Cirocchi R, Desiderio J, Guarino S, Santoro A, Parisi A, et al. Systematic review and meta-analysis of randomized clinical trials comparing single-incision versus conventional laparoscopic cholecystectomy. Br J Surg 2013;100:191-208.

11. Ahn SR, Kang DB, Lee C, Park WC, Lee JK. Postoperative pain relief using wound infiltration with $0.5 \%$ bupivacaine in singleincision laparoscopic surgery for an appendectomy. Ann Coloproctol 2013;29:238-42.

12. Roberge CW, McEwen M. The effects of local anesthetics on postoperative pain. AORN J 1998;68:1003-12. 